\title{
Saimiriine Herpesvirus 2
}

National Cancer Institute

\section{Source}

National Cancer Institute. Saimiriine Herpesvirus 2. NCI Thesaurus. Code C90038.

A virus in the family herpesviridae and the type species of rhadinovirus. It is an enveloped virus with a genome consisting of a sing le segment of double-stranded DNA that is approximately $112 \mathrm{~kb}$ in length. It normally infects squirrel monkeys, where it creates a persistent infection. 